\title{
İstanbul Hükümeti'nin Milli Mücadeleye Karşı Yeni Bir Taktiği: Sadâkatnâmeler
}

\author{
Yrd. Doç. Dr. Şaduman HALICI
}

\section{$\ddot{O Z E T}$}

Anadolu İhtilâli, Mustafa Kemal Paşa'nın 19 Mayıs 1919'da Samsun'a ayak basmast ile başladı. İstanbul Hükümeti, işgalci devletlerden aldı̆̆ tüm desteğe karşın Türk halkının Mustafa Kemal çevresinde bütünleşmesini önleyemedi. 23 Nisan 1920'de olağanüstü yetkili meclisin açılması, ulusun, yazgısını kendi eline almast ve tek egemen gücün Türk ulusunu temsil eden Büyük Millet Meclisi olduğunun vurgulanmast, Istanbul Hükemeti'ni yeni önlemler almaya itti. Sadrazam Damat Ferit Paşa 24 Nisan'da bir genelge yayınlayarak sivil asker herkesi Padişaha "sadâkat ve her emrine itaat" göstermeye çağırdt. Bu amaçla "Sadâkatnâme” başlıklı kağıtlar bastırıldı. Yapılacak törenlerle yemin işleminin gerçekleştirilmesini istedi. Yemin eden pek çok sivil ve asker kamu görevlisi arasında Kâzım Karabekir Paşa, Erzurum Valisi Reşid Bey ve Ankara Vali Vekili Yahya Galib Bey de vardı.

Anahtar Kelimeler: Sadâkatnâmeler, Mustafa Kemal Paşa, İstanbul Hükümeti, Damat Ferit Paşa, Kâzım Karabekir

\section{A New Tactic of İstanbul Government Against National Struggle: Loyalty Papers (Sadâkatnâmeler) ABSTRACT}

Anatolian Revolution started when Mustafa Kemal set foot on Samsun on $19^{\text {th }}$ May, 1919. Although İstanbul Government took the full support of occupying countries, they could not prevent the unification od Turkish public around Mustafa Kemal. The opening of Assembly with extraordinary authority of $23^{\text {rd }}$ April 1920,

•Anadolu Üniversitesi, Edebiyat Fakültesi, Tarih Bölümü. 
nation's decision to take their destiny unfer their own control, and emphasizing that the only sovereign power is the Grand National Assembly representinge Turkish nation forced İstanbul Government to take new precautions. Grand vizier Damat Ferit Paşa published a notice on $24^{\text {th }}$ April, and he called all civilians and military services to s how loyalty to Sultan and obedience to every order coming from Sultan. For this purpose Logalty Papers (Sadekatname) were printed. He wanted oathtaking ceremonies to be organized. Kâzım Karabekir, Erzurum Governor Reşid and Ankara Govemor Deputy Yahya Galip were some of the civilians, soldiers and public officers who signed and took oath.

Key Words: Loyalty Papers (Sadâkatnâmeler), Mustafa Kemal Paşa, İstanbul Government, Damat Ferit Paşa, Kâzım Karabekir Paşa.

Mustafa Kemal Paşa'nın 19 Mayıs 1919'da Samsun'a ayak basması ile başlayan Anadolu İhtilâli, emperyalist devletlere ve onların yerli işbirlikçilerine karşı yürütülen silahlı bir mücadele olmasının yanı sıra İstanbul Hükümeti ile girişilen yetki savaşının tüm özelliklerini de içeriyordu.

Bu mücadele, Mustafa Kemal Paşa'nın, 3 Haziran 1919'da Harbiye Nezareti'ne çektiği telgrafla başladı. 22 Haziran'da kamuoyuna duyurulan Amasya Genelgesi ile sürdü. Türk halkı da bir yandan Müdafaa-i Hukuk ve Redd-i İlhak ruhuyla örgütlenmeye başlarken öte yandan İzmir'in işgali ile gelen vahşet haberlerine Üsküdar, Fatih ve Sultanahmet mitingleri ile karşılık vererek tepkisini dışa vurdu. ${ }^{1}$ Geleceğini İtilaf devletlerine, özellikle İngiltere'ye bağlayan Saray ve onun hükümeti ise halkın duygularını önemsemedi, daha ötesi işgallere direnilmemesini istedi. Oysa Mustafa Kemal Paşa, tepki gösterilmesinden yanaydı. Halkta oluşan "tezâhürât-1 milliyeyi men' ve tevkif içün" ne kendisinde ne de hiç kimsede "kudret ve takat"ın olmadığını vurgulayarak ${ }^{2}$ Türk halkının duyarlılığını destekledi. Bu tavrı nedeniyle İstanbul Hükümeti Mustafa Kemal’i 9. Ordu Müfettişliği görevinden alarak etkisiz kılmak istedi. Mustafa Kemal Paşa ise hem bu görevinden hem askerlik mesleğinden istifa etti. Mustafa Kemal Paşa, mücadelesini "sine-i millet"te yürütme kararı alırken, İstanbul Hükümeti Onun etrafında bütünleşme eğilimi gösteren ulusal uyanışı kırma çabalarına hız verdi. Erzurum kongresini engellemek istedi. Sivas Kongresi'ni

${ }^{1}$ Ayrıntılı bilgi için bkz. Kemal Arıburnu, Milli Mücadelede İstanbul Mitingleri, 2.b., Ankara: Yeni Desen Matbaası, 1975; Mehmet Şahingöz, "İzmir'de Yapılan Maşatlık Mitingi ve İzmirlilerin İssâle Tepkisi”, Ege Üniversitesi Edebiyat Fakültesi Tarih Încelemeleri Dergisi IV, İzmir 1988, s. 53-60; "Maraş ve İstanbul'un Issgâli Üzerine Erzurum'da Yapılan Protesto ve Mitingler", Türk Yurdu, C. 9, Sayı: 20, 1988, s. 17-21: "Millî Mücâdele Esnasında Güneydoğu Anadolu Bölgesinde Yapılan Millî Birlik ve Beraberlik Mitingleri”. Atatürk Araştırma Merkezi Dergisi, Cilt X, Temmuz 1995, No. 32, s.417-432.

${ }^{2}$ Gazi Mustafa Kemal, Nutuk, Ankara, 1927, s. 16-17. 
engellemek için Ali Galip ile anlaştı. ${ }^{3}$ Ülkenin dört bir yanında ulusalcı düşünce karşıtı ayaklanmaları körükledi, Türk'ü Türk'e kırdırttı. Ancak ulusun, Anadolu ve Rumeli Müdafaa-i Hukuk Cemiyeti çatısında bütünleşmesini engelleyemediği gibi kongrelerde alınan parlamentonun toplanması ve ülke yazgısına el koyması kararlarına uymak zorunda kaldı.

Damat Ferit Paşa'nın istifa etmesi ve Ali Rıza Paşa Hükümetinin kurulması, seçimlere giden yolu açtı. 12 Ocak 1920'de toplanan Meclis-i Mebusan'ın 28 Ocak tarihli gizli oturumunda Misak-1 Milli'nin kabulü ve 17 Şubat'ta ilânı, işgal bölgelerinde halkın gösterdiği direnç, özellikle Urfa ve Maraş'taki savunma, İtilaf güçlerini daha etkin önlemler almaya itti: 16 Mart 1920 'de İstanbul işgal edildi. ${ }^{4}$ İstanbul Hükümeti işgalcilere boyun eğip halka "kemal-i sükûn ile iş ve güçleriyle meşgul olmaları" tavsiyesinde bulunurken Mustafa Kemal, ertesi gün yayınladığı genelge ile işgali, Meclisin basılmasını, kimi milletvekillerinin tutuklamasını Osmanlı Devleti'nin egemenliğinin sonu olarak değerlendirdi. ${ }^{5}$ Aynı gün İstanbul ile resmî ve özel tüm telgraf haberleşmesi yasaklandı. 18 Mart'ta Meclis-i Mebusan üyeleri, "güvenli bir ortamda görev yapma olanağının doğmasına kadar" görüş̧melerini ertelerken Mustafa Kemal Paşa, 19 Mart'taki genelgesi ile Ankara'da olağanüstü yetkilerle donatılmış bir meclisin toplanabilmesi için seçimlerin nasıl yapılacağını açıkladı. ${ }^{6}$ Ülkenin yeniden seçim atmosferine girdiği, İstanbul'da "millici", "kuvvacı" avının sürdüğü, Anadolu'ya aydın ve asker göçünün hızlandığı bu günlerde İstanbul ile Anadolu arasındaki yetki savaşı 5 Nisan'da Damat Ferit Paşa'nın 4. kez kabinesini kurması ile şiddetlendi. İstanbul Hükümeti 'Paşalık' rütbesi verdiği Anzavur'u Karesi (Balıkesir) mutasarrıfı olarak atadı.? "Kuva-yı Milliye"yi yok etmekle görevlendirdi. 10 Nisan'da Şeyhülislâm Dürrizade Abdullah Efendi'nin Kuva-yı Milliye'yi kâfir ilân eden ve katlinin vacip olacağını bildiren fetvası yayınlandı. ${ }^{8} 18$ Nisan'da İngiliz desteğiyle "Kuvayı İnzibatiye" adı verilen Halife Ordusu; "(Kuva-yı Milliye) nâmı tahtında ... ahalinin emvâl ve nukûdunu cebren ahz ve gasb ve katl eden erbâb-1 şekâveti te'dib ve tenkil içün" kuruldu. ${ }^{9}$ İstanbul Hükümeti'nin bu tavrına karşıllı Heyet-i Temsiliye de önlem almakta gecikmedi. 6 Nisan'da kurulan

${ }^{3}$ Sina Akşin, İstanbul Hükümetleri ve Milli Mücadele [Mutlakiyete Dönüş 19181919], C. I, İstanbul: İş Bankası Kültür Yayınları, 2004, s. 518-607.

${ }_{4}^{4}$ Türk İstiklal Harbi-Batı Cephesi (TiH), C. II, Kısım: 2 (4 Eylül 1919-9 Kasım 1920), Ankara: Genelkurmay Basımevi, 1965, s. 97-104; Bilge Criss, İsgal Altında İstanbul, İstanbul: İletişim Yayınları, 1993; Fahir Armaoğlu, "İngiliz Belgelerinde İstanbul'un İşgali", Belleten, C. LXII, Sayı: 234, Ağustos 1998, s. 467-494.

${ }_{5}^{5}$ Gazi Mustafa Kemal, Nutuk, Ankara, 1927, s. 265.

${ }^{6}$ y.a.g.e., s. 266-267.

${ }_{7}^{7}$ Peyam-1 Sabah, 9 Nisan 1336/1920, No: 491, s. 1.

${ }^{8}$ Takvim-i Vekayi, 11 Nisan 1336/1920, No: 3824, s. 1; Alemdar, 11 Nisan 1336/1920, No: 2780-480, s. 1.

${ }_{9}^{9}$ Kararname için bkz. Takvim-i Vekayi, 24 Nisan 1336/1920, No: 3837, s. 3 vd; Alemdar, 25 Nisan 1336/1920, No: 2793-493, s. 2. 
Anadolu Ajansı ile kamuoyunu yönlendirecek etkin bir propaganda aracını faaliyete geçiren Mustafa Kemal, bir yandan seçim çalışmalarını yürütürken öte yandan askerî önlemler almaya yöneldi. 15 Nisan'da Çerkes Ethem kuvvetleri Susurluk ve Kirmastı arasında Anzavur kuvvetlerini yendi ve tamamen dağıttı. Yapılan izleme harekâtı sonucunda Anzavur yaralı olarak Karabiga'dan gemi ile İstanbul'a kaçtı. ${ }^{10} 16$ Nisan'da İstanbul'un fetvasına Ankara müftüsü Rıfat (Börekçi) Efendi'nin fetvası ile yanıt verildi. "Vakıa ve hakikate gayr-1 muvafık olarak sâdır olan fetvaların şer'an mutâ' olamayacağını" bildiren bu fetva, Anadolu'da yüzlerce müftü ve din bilginince onaylanıp imzalanarak ajans ve gazeteler aracılığ duyuruldu. ${ }^{11}$

Gerek İstanbul Hükümeti'nin, gerekse işgal güçlerinin aldığı tüm önlemlere karşın Anadolu'ya silah ve cephane kaçırılması hız kazandığı gibi sivil ve asker aydınların göçü de durmadı, arttı. ${ }^{12} 2$ Nisan'da Halide Edip Hanım, Dr. Adnan (Adıvar), Hüsrev (Gerede), Yunus Nadi, Yusuf Kemal, Rıza Nur, Abdullah Azmi, Hoca Vehbi, Cami (Baykurt) beyler, ertesi gün de İsmet (İnönü), Celâlettin Arif, Saffet (Arıkan) beyler Ankara'ya ulaştılar. Mustafa Kemal Paşa, Yunus Nadi'yi kabulünde "...milletin istiklâlini vatanın son kaya parçası üzerinde müdafaa edeceğiz, kurtaracağız veya -eğer mukadderse- öleceğiz. Fakat eminiz ki ölmeyeceğiz ve kurtaracağız" diyerek mücadelelerindeki kararlılığını vurguladı. Bu kararlılığını, ülkedeki tüm askerî güçleri Heyet-i Temsiliye emrinde birleştirmekte de gösterdi. 9 Nisan'da 56. Fırka Kumandanı Albay Bekir Sami Bey'den, İstanbul ile bağlarını koruyan 14. Kolordu Komutanı Yusuf İzzet Paşa'nın -gerekirse tutuklu olarak- Ankara'ya getirilmesini, Yüzbaş1 Selâhattin Bey'den ise bu konuda Bekir Sami Bey "üzerinde kudretinin son haddini" kullanmasını hatta engel olmaya kalkarsa onun da tutuklamasını istedi. ${ }^{13}$ Bekir Sami Bey ile 61. Fırka Kumandanı Kâzım (Özalp) Bey’e, ulusal birliği bozacak davranışta bulunan mülkî ve askerî görevlileri görevden alabileceklerini,

${ }^{10}$ TïH, C. II, Kısım: 2, s. 42; Rahmi Apak, İstiklâl Savaşında Garp Cephesi Nasıl Kuruldu, İstanbul: Güven Basımevi, 1942, s. 108. Ayrıca bkz. Uluğ İğdemir, Biga Ayaklanması ve Anzavur Olayları (Günlük Notlar), Ankara: TTK Basımevi, 1989. İbrahim Sadi Öztürk, Ulusal Kurtuluş Mücadelesinde İç İsyanlar. Ankara: Fark Yayınları, 2007.

${ }^{11}$ Utkan Kocatürk, Atatürk ve Türkiye Cumhuriyeti Tarihi Kronolojisi (1918-1938), Ankara: TTK Basımevi, 2000, s. 150; Şerafettin Turan, Türk Devrim Tarihi, 2. Kitap, İstanbul: Bilgi Yayınevi, 1998; s.127-129.

${ }^{12}$ Ayrıntılı bilgi için bkz. Mesut Aydın, "Milli Mücadele Döneminde Anadolu'da Giriş ve Çıkışları Kontrol Altında Tutan Kuruluşlar”, Atatürk Yolu, C. 2, S. 5, s. 85-96; Mesut Aydın, "Milli Mücadele Yıllarında Türkiye Büyük Millet Meclisi Lehinde İstanbul'da Faaliyet Gösteren Bir Gurup: Zabitan Grubu”, OTAM, I (1990), s. 11-27; Hüseyin Dağtekin, "İstiklal Savaşında Anadolu'ya Kaçırılan Mühimmat ve Askeri Eşya Hakkında Tanzim Edilmis Mühim Bir Vesika”, Tarih Vesikaları Dergisi, I (16), s. 9-15; Bilâl Şimsir, Malta Sürgünleri, İstanbul: Bilgi Yayınevi, 1985. 272.

${ }^{13}$ Atatürk'ün Bütün Eserleri, C. 7 (1920), İstanbul: Kaynak Yayınları, 2003, s. 271- 
hatta tutuklayabileceklerini de belirtti. ${ }^{14}$ Böylece ülkedeki tüm asker ve sivil bürokratlar üzerinde Anadolu'nun otoritesini sağlamaya yöneldi.

İstanbul'la olan hiyerarşik bağlarını koruyan sivil bürokratlarla ordu ve kolordu komutanlarının Anadolu'ya verdiği destek de gün geçtikçe artıyordu. Kastamonu Valisi Cemal Bey, daha İstanbul'un işgalinin ertesinde, 17 Mart'ta, Mustafa Kemal Paşa'ya çektiği telgrafla vilayetinin "bugünden itibaren ... Heyet-i Temsiliye'yi Hükümet Merkezi” saydığını belirtti. ${ }^{15} 6$ Nisan'da 61. Tümen Komutanı Albay Kâzım (Özalp) Bey, 14. Kolordu ile ilgisini kestiğini Heyet-i Temsiliye'ye bildirdi. ${ }^{16}$ İstanbul Hükümeti ile yakın ilişkide olan 12. Kolordu Komutanı Fahrettin (Altay) Bey ile Yusuf İzzet Paşa ise Nisan ayı içinde Heyet-i Temsiliye emrine girdiklerini bildirdiler.$^{17} 20$ Nisan'da ise Fevzi Paşa (Çakmak) Anadolu'ya geçmek üzere Kuşçalı'ya ulaştı. 22 Nisan'da da Mustafa Kemal Paşa bütün vilayetlere gönderdiği genelge ile " 23 Nisan'dan itibaren bütün mülkî ve askerî makamların ve umûm milletin mercii(nin)" açılacak olan meclis olacağını ilân ederek ${ }^{18}$ yetkinin, Ankara'da ulus temsilcilerinden oluşacak mecliste olduğunu vurguladı.

Nihayet 23 Nisan 1920'de olağanüstü yetkili meclisin açılması, ulusun, yazgısını kendi eline alması ve tek egemen gücün Türk ulusunu temsil eden Büyük Millet Meclisi olduğunun vurgulanması, İstanbul Hükümeti'ni yeni önlemler almaya itti. Damat Ferit Paşa, Sadrazam ve Harbiye Nazır Vekili sıfatlarıyla 24 Nisan'da bir genelge yayınladı. "Bilcümle erkân, ümera ve zâbitan(1)" ".. şems-i şevket ve ikbâli asırlarca aleme şa'şaa-paş(parıltılı) olmuş o muazzam taht-1 saltanat ve hilafetin etrafinda" toplanmaya çağırdı. Bütün mesaisini, “...bazı sui tefehhümâtdan dolayı muğfel olarak meslek-i itaatten inhiraf etmiş olan ümera ve zabitânın yahud altı aydan beru hükümet-i merkeziyyenin idrak ve tefehhümü müşkül, muğlak ve mütereddid harekâtından dolayı bir cereyân-1 nâ-meşrua bil-zarur tâbiiyyet eden refiklerimizin daire-i istikâmet ve itaate avdetleri esbâbını istihzâra" ayıracağını belirten, "nifak ve ulü-l-emre itaatsizlik" nedeniyle vatanın, hatta ırkın tehlikeye girdiğini söyleyen Damat Ferit Paşa, "neferden müşire kadar cümlemiz kanun ve Padişahımız Efendimiz Hazretlerine itaatle mükelleftir" diyerek herkesi Padişaha "sadâkat ve her emrine itaat" göstermeye çağırdı. ${ }^{19}$ Ardından da devlet hizmetinde bulunan tüm görevlilerin sadâkat yemini etmesi kararlaştırıldı. Bu amaçla "Sadâkatnâme" başlıklı kağıtlar bastırıldı.

\footnotetext{
${ }^{14}$ Kocatïrk, a.g.e., s. 146-149.

${ }^{15}$ Kâmil Erdaha, Millî Mücadelede Vilâyetler ve Valiler, İstanbul: Remzi Kitabevi, 1975 , s. 224 .

${ }^{16}$ Kocatürk, a.g.e., s. 148.

${ }^{17}$ Kâzım Karabekir, İstiklâl Harbimiz, İstanbul: Türkiye Basımevi, 1960, s. 566.

${ }^{18}$ Gazi Mustafa Kemal, Nutuk, s. 274

19 “Mühim Bir Tamim", Alemdar, 25 Nisan 1336/1920, No: 2793-493, s. 1
} 
Bu kağıtların tüm kamu görevlilerine dağıtılarak imzalatılması, imzalayanların yeminlerine sadık kalmalarının sağlanması öngörüldü.

Sadâkatnâmeler; siviller ve askerler için olmak üzere iki türlü düzenlendi. Sivil görevliler şöyle yemin edecekti:

"Şevketlu Halife ve Sevgili Padişahımız Sultan Mehmet Han-ı Sâdis Efendimiz Hazretlerinin her türlü evâmir-i şahanelerine mûti' ve münkad kalacağıma ve iktiza-yı halde uğur-1 Hilâfetpenâhîlerinde feda-yı cana hazır ve âmade bulunduguma ve memuriyette bulunduğum müddetce siyasetle kat'iyyen iştigal etmeyeceğime ve Hükümet-i Osmaniye'nin rıza-yı âlisi hilafında bir fiil ve harekette bulunmayacağıma

Vallah, Tallah, Billah"

Askerlerin yeminlerinin başlangıç ve son bölümde kimi değişiklikler vardı. Şöyle ki:

"Baş Kumandan-1 Âzam ve Akdesimiz Şevketlu Halife ve Hakanımız Padişahımız Sultan Mehmet Han-1 Sadis Efendimiz Hazretlerinin her türlü evâmir-i şahanelerine mûti' ve münkad kalacağıma ve iktizay-1 halde uğur-1 Hilâfetpenâhîlerinde feda-yı cana hazır ve âmade bulunduğuma ve silk-i askeriyede kaldığım müddetçe siyasetle kat'iyyen iştigal etmeyeceğime yemin ederim.

Vallah, Billah, Tallah"20

Damat Ferit Paşa, 26 Nisan 1920 tarih 139 numaralı sadaret emri ile tüm sivil ve askerî birimlere Sadâkatnâme örneklerini gönderdi. Yapılacak törenlerle yemin işleminin gerçekleştirilmesini istedi. Sadrazamın emri üzerine her birim de kendisine bağlı sivil ve askerî makamlara emirnâmeler gönderdi. Bu çerçevede, örneğin Posta ve Telgraf Umum Müdürü Refik Halid Bey, tüm şube ve kalem müdürlüklerine yemin örneklerini tebliğ ederek törenlerle bu yeminin yapılmasını istedi. ${ }^{21}$

Sadâkatnâmelerin imzalanması törenle yapıldı. Siviller, kağıtlarını müdürlerin önünde okuyup imzalıyor, kendi künyelerini de yazıyorlardı. Askerler ise kumandanlarının önünde okuyup imzalıyor, isim, rütbe ve görevlerini belirtiyorlardı. Örneğin; İstanbul'da binbaşı, yarbay, albay ve daha alt rütbeli subaylarla askerî memurlardan oluşan toplam 128 kişi ve 139 erin yeminleri 2. Alay Müfettişi Mehmet Sabit bin Ahmed, Ağır Topçu 1. Liva Kumandanı Kaymakam Hüseyin Şükrü, İnşaat-ı İstihkâmiye Komisyonu Reisi Miralay Mehmed Refik ve Karadeniz Mevki-i Müstahkem

2) "Teyid-i Sadâkat", İleri, 5 Mayıs 1336/1920, No: 830; "Sadâkatnâmeler", Vakit, 14 Mayıs 1336/1920.

21 "Teyid-i Sadâkat", İleri, 5 Mayıs 1336/1920, No: 830, s. 2; İleri, 14 Mayıs 1336/1920, No: 839 , s. 3 . 
İSTANBUL HÜKÜMETININ MILLLI MÜCADELEYE KARȘI YENİ BİR..... 631

Kumandanı Miralay Yusuf Ziya bin Hüseyin beylerin gözetiminde yapılmıştı. ${ }^{22}$

İmzalanan sadâkatnâmeler toplu olarak ait oldukları makama teslim edildi. Hem imzalanan sadâkatnâmeler hem de onlarla birlikte gönderilen bağlılık telgrafları gazetelerle kamuoyuna da duyuruldu.

5 Mayıs 1920 tarihli Alemdar gazetesi "Teyid-i Sadâkat" başlı̆̆ ile verdiği haberde "erkân, ümera ve memurin-i askeriyye"nin Padişah ve hükümete sadâkatlerini bildirdiklerini vurguladı ve iki sütun halinde isim listesi verdi. 14 Mayıs'ta ise "Ordudan Yükselen Sadâkat Sesi”ni sütunlarına taşıdı. Fatih, Aksaray ve Süleymaniye Ahz-ı Asker Şubesi, Onuncu Topçu Alayı Kumandanlığı, Kavak Mevki-i Müstahkem Kumandanlığı ile Altmış Üçüncü Topçu Kumandanlığından gelen beyannamelere yer verdi. ${ }^{23}$

Bunlardan Fatih Ahz-1 Asker Subesi'nde görevli olan askerlerin yemin töreninin ardından, töreni gerçekleştiren Sultanahmed Ahz-1 Asker Şubesi Reisi Binbaşı Ahmed Hamdi, Yüzbaşı Saadeddin, Yüzbaşı Ramiz, Yüzbaşı Fazlı ve Mülâzım-1 evvel Halis beylerden oluşan komisyon, Şube başkanlığına 3 Mayıs'ta ayrıca şu beyannâmeyi de gönderdi.

"Beşinci Fırka Fatih Ahz-1 Asker Riyaset-i Âliyesine

26-4-36 tarih ve 139 numarolu zeyl-i riyasetpenâhîleriyle tebliğ buyurulan beyannâme-i sâmi-i nezâretpenâhi ahkâm-1 münderecesine itlâ' hâsıl olmuşdur.

Askerliğin üss-ül esâsı olan ulü-1-emre itaati askere duhûlümüzden beri bir farîza add eden ve Baskumandan-1 Akdesimiz Hilâfetpenâh Efendimiz Hazretlerine karşı bu farîza-i itaat ve inkıyâdı şimdiye kadar halel-dâr etmemiş bulunan zîrde vâzı'-1 imzâ Sultanahmed Ahz-1 Asker Şubesi zâbitânı bâdemâ dahi meslek-i kadîm ve ubûdiyyetden inhirâf etmeyerek Başkumandan-1 Akdes-i Hilâfetpenâh Efendimiz Hazretlerine ve kavânîn-i mevzûa-i devlete münkad ve ifâ-yı vazifeye müdâvim bulunduğumuz mâruzdur." 24

14 Mayıs 1920 tarihli Vakit gazetesinde ise;

"Aksaray, Eyüp, Sultanahmet, Süleymaniye, Fatih, Makriköy Ahz-1 Asker şubeleri reis ve zabıtânı ile Mevki-i Müstahkem Ağır Topçu İkinci ve Altmış Üçüncü ve Onuncu Topçu Alayları kumandanları ve zabitânı imzalarını muhtevî ve Harbiye Nezaret-i Celîlesi tamimine göre Kumandan-1 zî-şânımız, Halife-i Muazzamımız Efendimiz Hazretlerine mutavaat ve

22 "Teyid-i Sadâkat", İleri, 5 Mayıs 1336/1920, No: 830, s. 2.

23 "Teyid-i Sadâkat" Alemdar, 5 Mayıs 1336/1920, No: 2803-503, s. 2; 14 Mayıs $1336 / 1920$, No: $2812-512$, s. 2

24 "Teyid-i Sadâkat", Alemdar, 5 Mayıs 1336/1920, No: 2803-503, s. 2. 
inkıyadına sabit ve daim bulunduklarını ve emr ü ferman-1 Hümâyûnlarına ve kavânîn-i mevzuaya her zaman olduğu gibi bütün mevcudiyyetleri ile tâbiyyet ve teşyid-i rabıta-i ubûdiyyet etmekle müftehir bulunduklarını mübeyyin ayrı ayrı Sadâkatnâmeler Harbiye Nezaret-i Celîlesine takdim edilmişdir" deniliyor, ardından yemin sureti veriliyor ve imzalayan askerlerin, görev, rütbe ve isimleri belirtiliyordu. ${ }^{25}$

Yine, 63. Ağır Topçu Alayı Kumandanlığı'ndan 55 imza ile Harbiye Nezareti'ne gönderilen sadâkatnâmelerde ayrıca, "asker için en büyük şeref ahkâm-1 şer'iyyenin ve kavânîn ve nizamât-1 devletin tayin ve tahdid eylediği hudud dahilinde harekete ve hiçbir cemiyet-i siyasiyyeye intisab etmeyerek namus ve hamiyyet dairesinde velinimet-i cihan Padişah-1 Osmanîden ve Halife-i İslâmiyet Efendimiz Hazretlerinin irâdât-1 seniyye-i mukaddeselerine mutavaat ve hin-i akdesde hayat cömerdliği müsabakasına girerek Padişah-1 ızamîlerinin uğrunda feda-yı candan ibaretdir" deniliyor ve "Ağır Topçu 63. Alayı teşkil eyleyen üç tabura mensub bilimum ümerâ ve zabitân ve memurîn ve efrad bu hissiyat-1 celîle ve cemîle ile mütehassıs olduğumuzu ve ulü-l-emre inkıyâdı bilcümle i'tikadât ve hissiyâtın fevkinde add eylediğimizi mübeyyen işbu mazbata(nın) bil-tanzim arz ve takdim kılındı" "̆ı̆ı belirtilerek Padişahın emirleri dışına çıkılmayacağı vurgulaniyordu. ${ }^{26}$

Makriköy (Bakırköy) Ahz-1 Asker Şubesi'nden beş imza ile 5. Fırka Fatih Ahz-1 Asker Kalemi başkanlığına hitaben yazılan sadâkat metninde ise "Halife-i mufahham, Başkumandan-1 1zam, sevgili Padişahımız Efendimiz Hazretlerine karşı min-el-kadîm perverde edegeldiğimiz hissiyât-1 sadâkat ve ubûdiyyetkâranemizi bu kere dahi te'yiden arz ve kavânîn ve nizamât-1 hükûmet-i seniyyelerine karşı mütehassıs bulunduğumuz itaat ve sadâkati bir vecîbe-i şükran ve mahmedet telakkîsiyle mübâhi olduğumuzun südde-i seniye-i cenâb-1 tâcidâr-1 ızamîlerine arz ve iblâğına delâlet ve vesâtet-i ulyâ-yı riyâsetpenâhilerini istirhâm ma'rûzuyla işbu mazbatamız takdim kılındı" deniliyordu. 10. Topçu Alayı tarafından 19 imza ile verilen sadâkat metninde ise "Resîd-i yed-i takdim olan nezâret-i celîle tamimi ahkâm-1 münîfesine tevfiken kumandan-1 zî-şânımız, Halife-i muazzamamız Padişahımız Efendimiz Hazretlerine mecbûr olduğumuz mutâvaat ve inkıyâda şimdiye kadar olduğu gibi ba'de-mâ sâbit ve dâim olduğumuzu emr ü ferman-1 hümâyûnlarına ve kavânîn-i mevzûaya her zaman olduğu gibi bütün mevcûdiyetimizle ta'biyet ve teşyîd-i râbıta-i ubûdiyyet etmekle müftehîr bulunduğumuzu ve ordunun mâ-bih-il kuvâı olan inzibâtı ihlâle cür'etten vatan-1 azîzimizin felâketini mûcib olacağı imânıyla öteden beri mu'tekid bulunduğumuzu arz ve bu münâsebetle tevâfür-i şan ü şevket Hilâfetpenâhîleri duasını vird-i niyaz eyleriz ferman" denilerek Padişahın

25 "Sadâkatnâmeler", Vakit, 14 Mayıs 1336/1920, No: 892, s. 3.

26 "'Teyid-i Sadâkat", İleri, 14 Mayıs 1336/1920, No: 839, s. 3. 
emri dışına çıkmayı, Kuvâ-yı Milliye yanlısı olmayı vatanın yok olması ile eş gören bir anlayış sergilendi. ${ }^{27}$

Gazetelerle ilân edilen sadâkatnâmelerde dikkati çeken bir özellik de Anadolu İhtilâli'nin başladığ 1 illerden gelenlere ve ihtilâlin simge isimlerine öncelik verilmesiydi. Amasya'dan Müftü Tevfik, Reis-ül ulemâ Mecdizâde Kâmil, Belediye Reisi Mustafa, Ticaret Reisi Süleyman, Miralayzâde Hamdi, Eşraftan Topçuzâde Ali, Eşraftan Mumcuzâde İsmail Hakkı, Mehmed bin zâde Lütfi, Nâkib-ül eşraf Mevlevî Şeyhi Cemaleddin, Eşraftan Topal Ağazâde Mehmed Ali, Çirkcizâde Sâdık, Yumuk Osmanzâde Hürrem, Çavuşluzâde Ahmed, Tiryakizâde Tahsin, Hacı Fevzizâde Mehmed, Mahmud bin zâde Hamdi, Kemerbaşıâdde Hüsameddin, Kavafzâde Mustafa, Kahvecizâde Mehmed, Şirinzâde Mahmud, Temizgellizâde Mehmed, Gürünzâde Osman, Hacı Ali Ağazâde Mahmud ve Börkçüzâde Ömer "her türlü âsâr-ı fevkalâde-i fedâkâriyi izhâra âmâde bulunan biz sâdık evlâdlarınız velâdet-i mes'adet-i makrûn-1 hümâyûnlarını tebrik vesile-j cemîlesiyle atebe-i seniyyelerine takdib-i ubûdiyyet ve ta'zimât ederek tevâfür-i ömr ü afiyed ve temâdî-i şan ü şevket-i hümâyûnları tazarruânında bulunduğumuzu arz eyleriz ferman" diyerek padişaha sadâkatlerini bildirdiler. ${ }^{28}$

Erzurum Valisi Reşid Bey ise 10 Nisan'da Harbiye Nezareti'ne çektiği telgrafla vilayetine bağlı askerî personelin yemin ettiklerini bildirdi. Yemin töreninin Kâzım Karabekir Paşa'nın da bulunduğu kalabalık bir kitle önünde yapıldığını bildirdi. Reşid Bey telgrafında şöyle diyordu: "Velâdet-i bâhir-ül meymenet Hazret-i Hilâfetpenâhîye müsâdif leyle-i sa'd-âyât olan bugün Hükümet Konağı pişgâhında Asâkir-i Mansûre-i Hazret-i Padişahî saffbeste-i ihtirâm olduğu halde On Beşinci Kolorduyu Hümâyûn Kumandanı ile erkân-1 kirâmı bilcümle memûrîn kullarıyla ulemâ ve ahâli-i beldeden bir cemm-i gafîr huzuruyla füzûnî-i ömr ü afiyet ve devam-1 şan u şevket Hazret-i Hilâfetpenâhîye be-hulüsü'l-bâl eda ve nâm nâmî'-i hümâyûn-1 cenâb-1 mülûkâneye olarak râsime-i tebrikât dâire-i hükûmet ve askerîde mütekâbilen icrâ edildiğinin tebrikât-1 mûr-âneye terdîfen arz-1 atabe-i ulyâ kılınması mâruzdur ferman.,"29

Kâzım Karabekir Paşa da yemin töreninin yapıldığını şu telgrafla Nezarete bildirdi.

"Velâdet-i Hümâyûn Hazret-i Hilâfetpenâhîleri mûtad olan merâsimin fevkinde olarak tebcîl olundu. Alem-i İslâmın âbide-i hayatı, emânât-1 celîle-i Hazret-i Peygamberînin mahfaza-i kudsiyyet-penâhı ve ecdâd-1 ızâm-1 hümâyûnlarının millete ve alem-i İslâmiyyete tuhfe-i muallâsı olan

\footnotetext{
27 "Teyid-i Sadâkat", İleri, 15 Mayıs 1336/1920, No: 840, s. 3 ,

28 "Teyid-i Sadâkat", Illeri, 7 Mayıs 1336/1920, No: 832, s. 2.

29 "Teyid-i Sadâkat", İleri, 7 Mayıs 1336/1920, No: 832, s. 2.
} 
pay-1 taht-1 saltanat-1 seniyyelerinin ve hukuk-1 âliye-i hilâfet ve saltanatının an-karîb-ül mücelliyât-1 cedîde-i müebbede ile masûniyyet-i ebediyyeye mazhar olmasını hatta kuvve-i beyzây-1 aliyesinden istî'taf olunduğu mâ'rız1 tebrik ü tehniyetde arz olunur. ${ }^{30}$

13. Kolordu Komutanı Miralay Cevdet Bey ise 10 Nisan'da Ankara'dan Harbiye Nezaretine çektiği telgrafla kolordusunun Padişaha bağlılı̆̆ını büyük bir coşku ile gösterdiğini bildirdi. Cevdet Bey şöyle diyordu: "Velâdet-i ber-meymenet-i Hazret-i Hilâfetpenâhîye müsâdif bugünkü yevm-i akdesde Kolordumun zabitân ve efrâdı du'â-yı bi-riyâ-yı cenâb-1 Padişahîyi ez-cân u dil tekrar etmişler ve mıntıkamın her tarafında bu yevm-i mübeccel vesilesiyle Halife-i zî-şânımız şerefine pek büyük tezâhürât yapılmış ve pek parlak merâsim-i tebrikiyye ifâ kılınmıştır. Zât-ı Akdes-i Hazret-i Hilâfetpenâhîye karşı Kolordumun beslemekde olduğu sadâkat ve ubûdiyyetin lâ-yetezelzel ve her zamandan ziyâde kavî olduğunun tebrikât-1 ubûdiyyetkâraneme terdîfen hâkipây-1 muallâ-yı cenâb-1 Padişahîye arzını istirham ederim ferman."

Ankara Vali Vekili Yahya Galib Bey de aynı gün yapılan resmî törenle sivil görevlilerin bağlılık yemini ettiklerini ve “... Devlet-i Âliyelerinin istiklâl ve istihlâsı uğrunda tarihinin şimdiye kadar kayd etmediği fedakârlıklara azm etmiş ve bu azîm ve imanında sevgili Padişahlarının kalb-i hümâyûnlarını daima kendileriyle beraber görmekte bulunmuş olan bütün milletin en yüksek nokta-i vahdeti(nin)" padişahta birleştirdiğini bildirdi. ${ }^{31}$

Kal'a-i Sultaniye(Çanakkale)'den Müftü Mustafa Rasim, Bedeliye Reisi Mehmed Rasih, Meşâyih-i Kadriyyeden Esseyid Mehmed, Meşâyih-i Nakşiyyeden Esseyid Mehmed Tevfik, Fatih Müderrisi Mehmed Necati, Fatih Cami-i Şerifi Hatib ve İmamı Ahmed Hamdi ile beldenin önde gelen isimleri de padişaha bağlılık yemininin ardından şu telgrafı gönderdiler:

"Huzur-1 Sâmi-i Hazret-i Sadaretpenâhiye

Evrâk-1 havadisle neşr ve tamîm buyurulan fetva-yı şerife ve hatt-1 hümâyûn-1 şâhâne ile merkez saltanat-1 seniyyenin beyannâme-i resmîsi mesâmi'-i mutâvaatımızı tezyîn eden biz Çanakkale ahali-i sâdıkası makâm1 Hilâfet-i uzmâya ve saltanat-1 seniyye-i ulyâya lâ-yetezelzel bir samimiyet-i vicdâniyye ile sâdık ve merbut bulunduğumuzu Hilâfet-i celîle ve saltanat-1 seniyyeden maada hiçbir kuvvetle irtibatımız bulunmadığını ve bu vesile ile makâm-1 muallâ-yı Hazret-i tacidâr-1 ızamiye arz-1 itaat ve sadâkat ve

${ }^{30}$ y.a.g.g. Kâzım Karabekir Paşa "İstiklâl Harbimiz"de konu ile ilgili herhangi bir bilgi vermemektedir.

31 "Teyid-i Sadâkat", İleri, 7 Mayıs 1336/1920, No: 832, s. 2. 
takdim-i ta'zimât ve ihlâsât-1 gayât eylediğimizi arz ve ifadeye ictisâr eyledik olbabda."

Çanakkale'nin önde gelen isimleri bu telgrafla Anadolu'yu ve ulusal güçleri tanımadıklarını ortaya koyarken, 25. Kolordu Kumandanlığı'na ${ }^{32}$ bağlı 132 subay, yemin töreninin ardından Harbiye Nezareti'ne gönderdikleri "taahhüdnâme" ile doğrudan doğruya Kuva-y1 Milliye'yi hedef aldı. Padişah'a bağlılıkları ile Anadolu'daki ulusal hareketi onaylamadıklarını da belirten bu taahhütnamede; "Kuva-yı milliye nâmı tahtında Anadolu'da teşekkül eden ve yer yer halkı dâire-i itaat ve inkıyâddan çıkaran kuvvetlerin harekât-1 bâgîyânesini hiçbir vechile tasvib etmediğimizi, onlar tarafından veya onların harekâtını mergub gören edânî cânibinden isnâd edilen tezvirâtı tamamen red ve tel'in eyleyeceğimizi, Başkumandan-1 1zam, Halife-i muazzam Efendimiz Hazretlerinin emr ü ferman-1 hümâyûnları dâiresinde hareket ve tevdî' kılınacak her türlü vezâifde cansiperâne hizmet en birinci âmâl-i âbidânemiz bulunduğunu arz ve bu münâsebetle tevâfür-i şan u şevket-i şahaneleri duâsını ref'-i bâr-geh-i ehaddiyye eyleriz."deniliyordu.

Ancak ne sadâkatnâmeler ne de Mustafa Kemal ve arkadaşları hakkında alınan idam kararları ${ }^{34}$ Türk ulusunu Mustafa Kemal'den ayırdı. Egemenliğine, Mustafa Kemal'in çabasıyla oluşturulan TBMM ile sahip çıkan Türk ulusu, Onun önderliğinde yürüttüğü mücadele ile ulusun birleşmesini ve bütünleşmesini sağladı. Böylece, tüm engellemelere karşın hem iç ayaklanmalar bastırıldı, hem de Anadolu düşmandan arındırıldı. Lozan Antlaşması ile de tam bağımsız yeni bir Türk Devleti'nin varlığı, çağdaş dünya devletlerine kabul ettirildi.

\section{KAYNAKÇA}

\section{Kitaplar}

Akşin, Sina, İstanbul Hükümetleri ve Milli Mücadele (Mutlakiyete Dönüş 19181919), C. I, İstanbul: İş Bankası Kültür Yayınları, 2004.

Apak, Rahmi, İstiklâl Savaşında Garp Cephesi Nasıl Kuruldu, İstanbul: Güven Basımevi, 1942.

${ }^{32}$ Kolordu İstanbul'da bulunuyordu. Kolorduya bağlı 1. Tümen İzmit'te, 10. Kafkas Tümeni İstanbul'da, 57. Tümen Çine'de (sonra Denizli) ve 56. Tümen ise Bursa'da idi. Bkz. Türk İstiklâl Harbi-Batı Cephesi, C.II, Kısım: 2 (4 Eylül 1919-Kasım1920), Ankara: Genelkurmay Basımevi, 1965, s. 15.

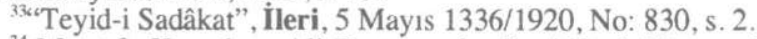

${ }^{34}$ Mustafa Kemal ve Ali Fuat paşalar ile Alfred Rüstem, Kara Vasıf, Adnan (Adıvar) beyler ve Halide Edip Hanım hakkındaki idam hükümleri 24 Mayıs 1920'de Vahdettin tarafından onaylandı. Padişah buyruğu için bkz. Ş. Turan, a.g.e., s. 305. 
Arıburnu, Kemal, Milli Mücadelede İstanbul Mitingleri, 2.b., Ankara, Yeni Desen Matbaası, 1975.

Atatürk’ün Bütün Eserleri, C. 7 (1920), İstanbul: Kaynak Yayınları, 2003.

Criss, Bilge, İşgal Altında İstanbul, İstanbul: İletişim Yayınları, 1993.

Erdaha, Kâmil, Millî Müicadelede Vilâyetler ve Valiler, İstanbul: Remzi Kitabevi, 1975.

Gazi Mustafa Kemal, Nutuk, Ankara, 1927.

İğdemir, Uluğ, Biga Ayaklanması ve Anzavur Olayları (Günlük Notlar), Ankara: TTK Basımevi, 1989.

Karabekir, Kâzım, İstiklâl Harbimiz, İstanbul: Türkiye Basımevi, 1960.

Kocatürk, Utkan, Atatürk ve Türkiye Cumhuriyeti Tarihi Kronolojisi (19181938), Ankara: TTK Basımevi, 2000

Öztürk, İbrahim Sadi, Ulusal Kurtuluş Mücadelesinde İç İsyanlar, Ankara: Fark Yayınları, 2007.

Şimşir, Bilâl, Malta Sürgünleri, İstanbul: Bilgi Yayınevi, 1985.

Turan, Şerafettin, Türk Devrim Tarihi, 2. Kitap, İstanbul: Bilgi Yayınevi, 1998.

Türk İstiklal Harbi-Batı Cephesi, C. II, Kısım: 2 (4 Eylül 1919-9 Kasım 1920), Ankara: Genelkurmay Basımevi, 1965.

\section{Makaleler}

Armaoğlu, Fahir, “İngiliz Belgelerinde İstanbul'un İşgali”, Belleten, C. LXII, Sayı: 234, Ağustos 1998.

Aydın, Mesut, "Milli Mücadele Yıllarında Türkiye Büyük Millet Meclisi Lehinde İstanbul'da Faaliyet Gösteren Bir Grup: Zabitian Grubu”, OTAM, I (1990)

, "Milli Mücadele Döneminde Anadolu'da Giriş ve Çıkışları Kontrol Altında Tutan Kuruluşlar", Atatürk Yolu, C. 2, S. 5.

Dağtekin, Hüseyin "İstiklal Savaşında Anadolu'ya Kaçırılan Mühimmat ve Askeri Eşya Hakkında Tanzim Edilmiş Mühim Bir Vesika", Tarih Vesikaları Dergisi, I (16).

Şahingöz, Mehmet, "İzmir'de Yapılan Maşatlık Mitingi ve İzmirlilerin İşgâle Tepkisi", Ege Üniversitesi Edebiyat Fakültesi Tarih İncelemeleri Dergisi, IV, İzmir 1988.

"Maraş ve İstanbul'un İşgâli Üzerine Erzurum'da Yapılan Protesto ve Mitingler", Türk Yurdu, C. 9, Sayı: 20, 1988. 
, "Millî Mücâdele Esnasında Güneydoğu Anadolu Bölgesinde Yapılan Millî Birlik ve Beraberlik Mitingleri”, Atatürk Araştırma Merkezi Dergisi, Cilt X, Temmuz 1995, No. 32

\section{Gazeteler}

Alemdar, 11 Nisan 1336/1920, No: 2780-480.

Alemdar, 25 Nisan 1336/1920, No: 2793-493.

“Mühim Bir Tamim”, Alemdar, 25 Nisan 1336/1920, No: 2793-493.

“Teyid-i Sadâkat”, Alemdar, 5 Mayıs 1336/1920, No: 2803-503.

“Teyid-i Sadâkat”, İleri, 5 Mayıs 1336/1920, No: 830.

“Teyid-i Sadâkat", İleri, 7 Mayıs 1336/1920, No: 832.

“Teyid-i Sadâkat”, İleri, 14 Mayıs 1336/1920, No: 839.

“Teyid-i Sadâkat”, İleri, 15 Mayıs 1336/1920, No: 840.

Peyam-1 Sabah, 9 Nisan 1336/1920, No: 491.

Takvim-i Vekayi, 11 Nisan 1336/1920, No: 3824.

Takvim-i Vekayi, 24 Nisan 1336/1920, No: 3837.

“Sadâkatnâmeler”, Vakit, 14 Mayıs 1336/1920. 


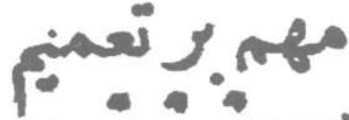

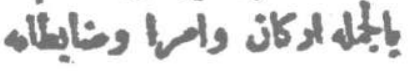

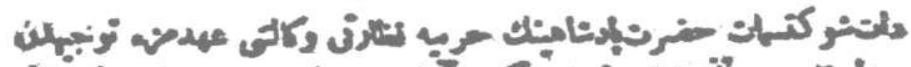

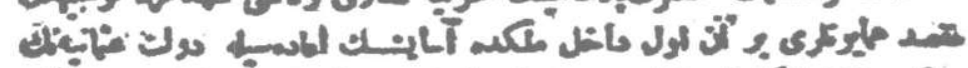

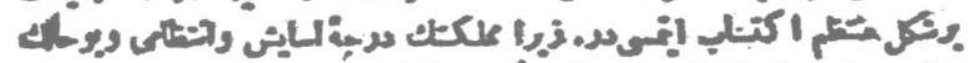

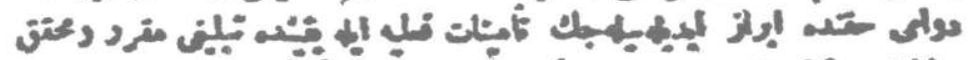

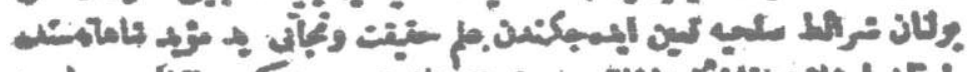

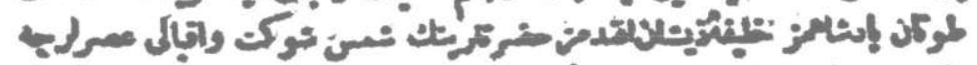

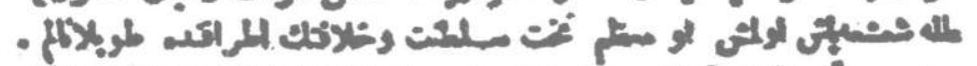

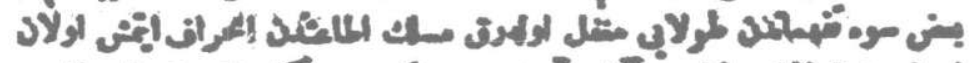

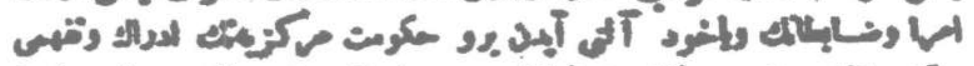

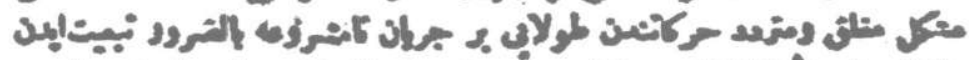

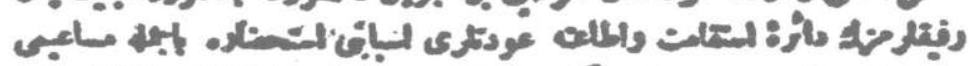

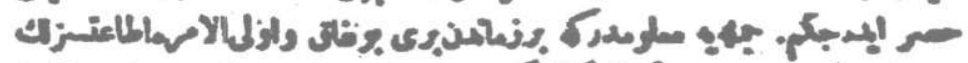

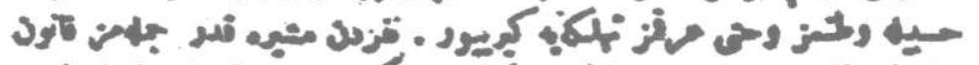

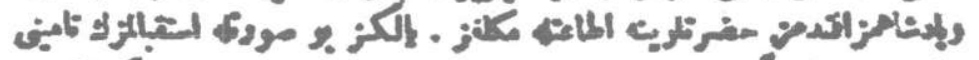

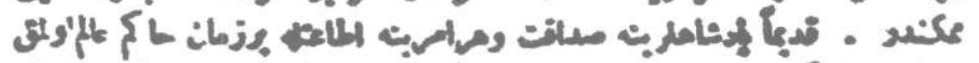

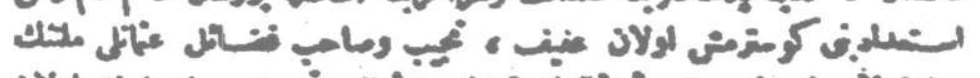

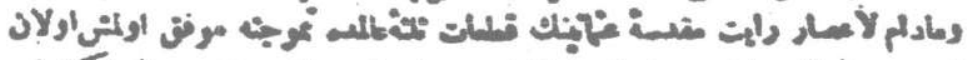

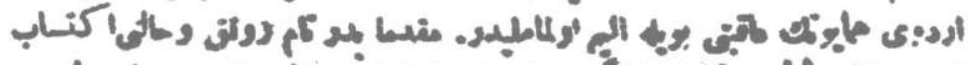

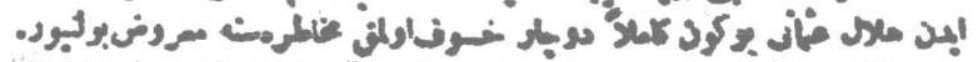

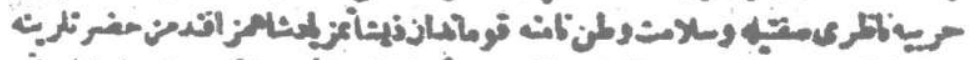

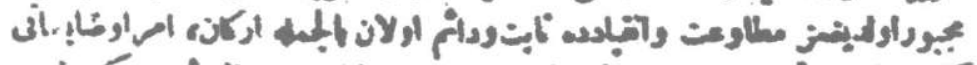

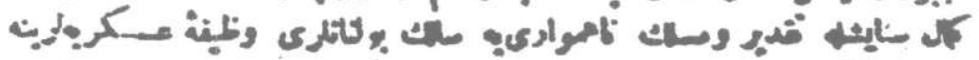

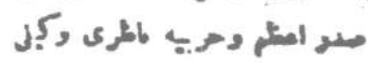

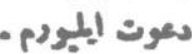

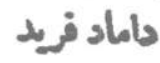




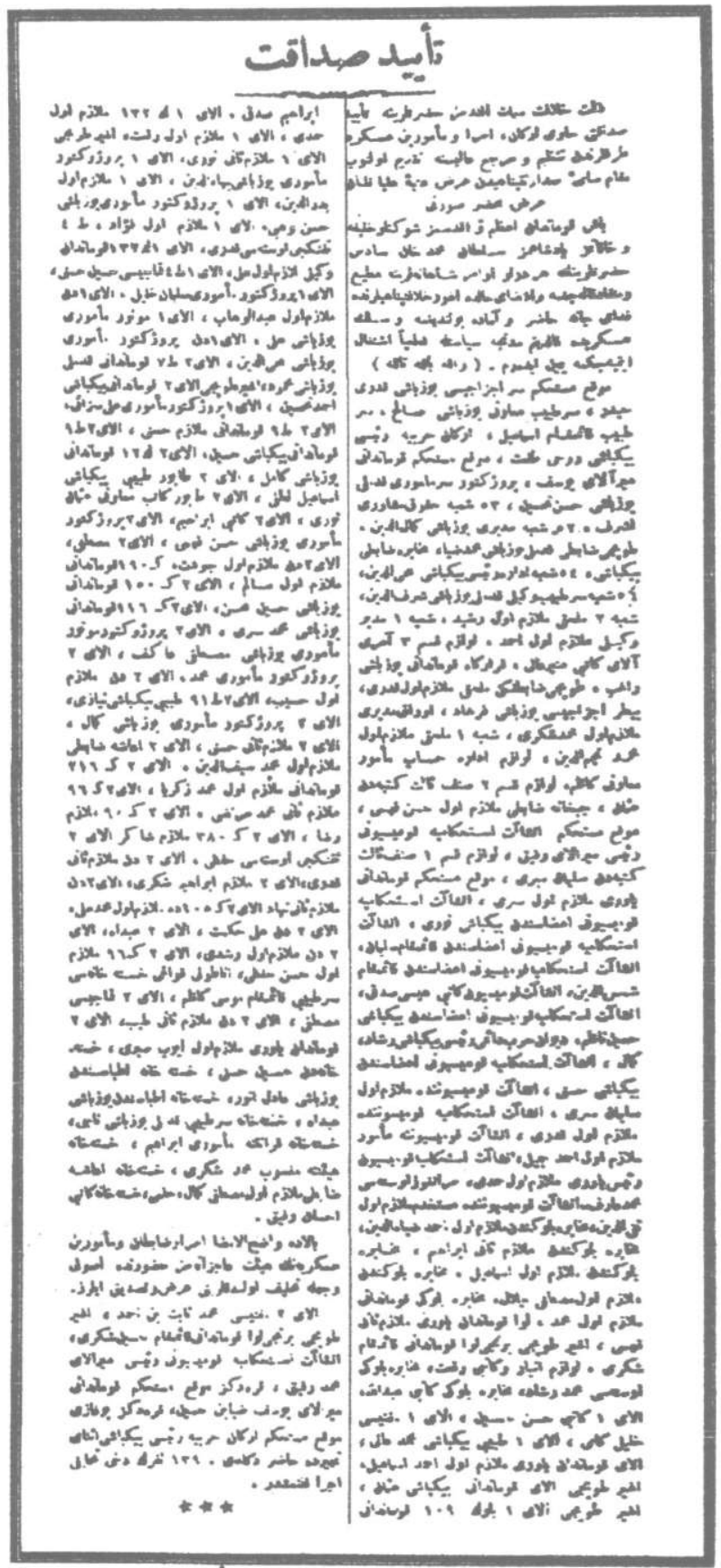

fleri, 5 Mayıs 1336/1920 


$$
\text { تأميد صبداقت }
$$

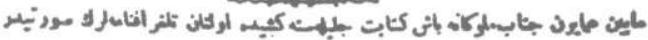

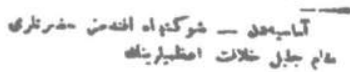

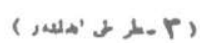

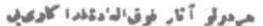

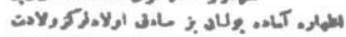

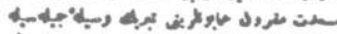

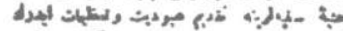

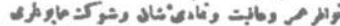

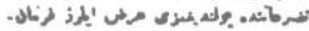

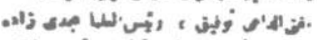
أن

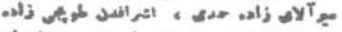

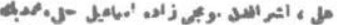

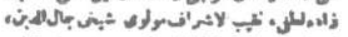

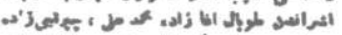

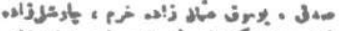

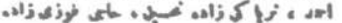

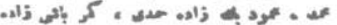

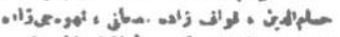

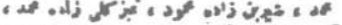

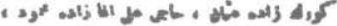

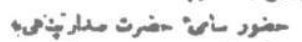

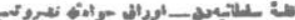

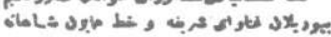

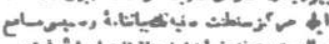

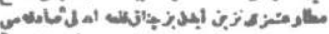

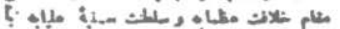

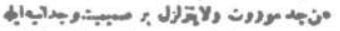

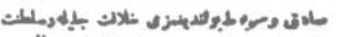

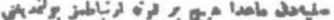

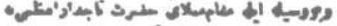

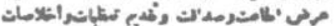

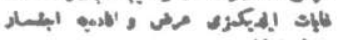

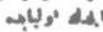

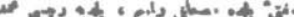

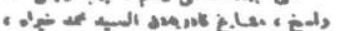

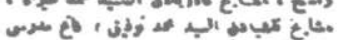

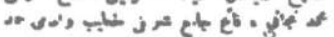

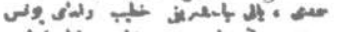

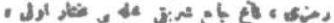

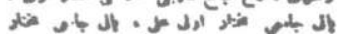

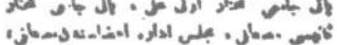

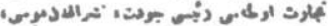

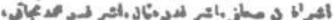

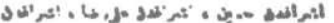

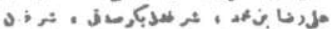

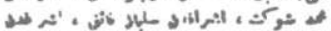

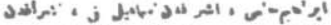

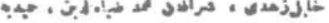

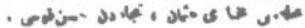

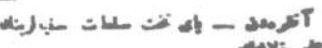

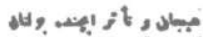

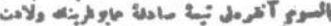

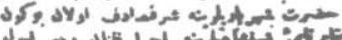

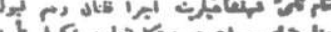

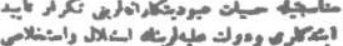

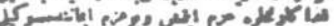

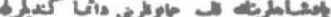

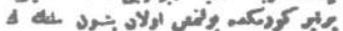

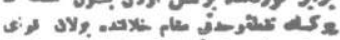

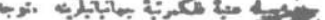

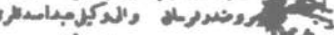
مع فالب.

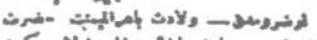
35

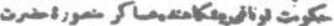
קst

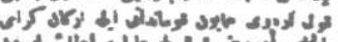

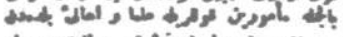

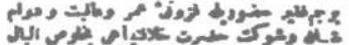

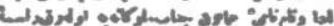

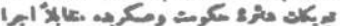

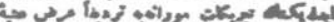

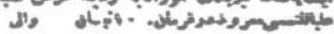
مُ

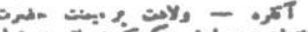

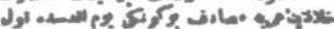

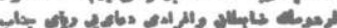

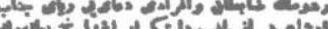

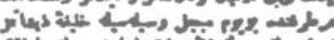

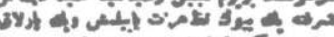

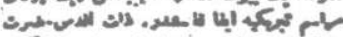

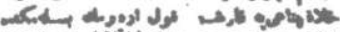

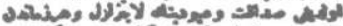

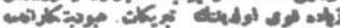
ع مان

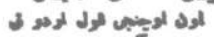

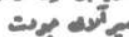

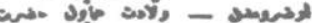

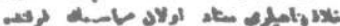

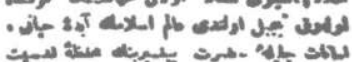

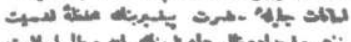

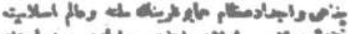

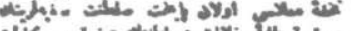

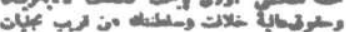

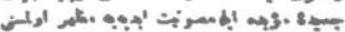

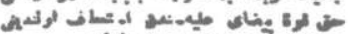

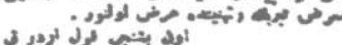

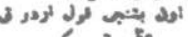

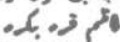

Ileri, 7 Mayıs 1336/1920 


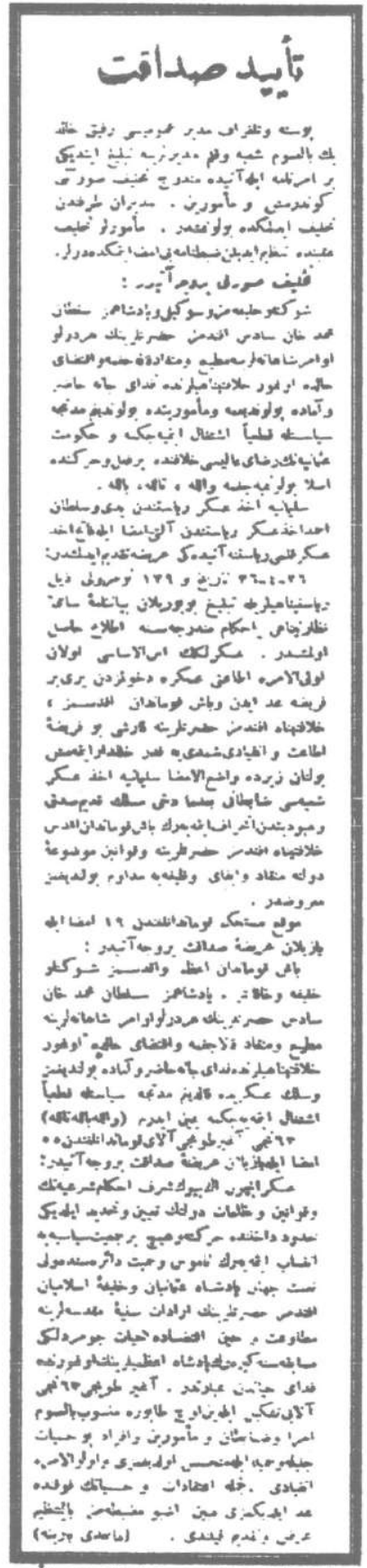

fleri, 14 Mayss 1336/1920 


\section{صوdساقتن:مdل}

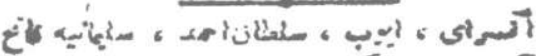

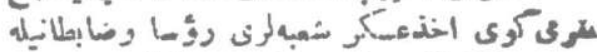

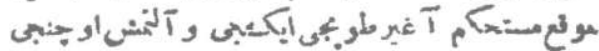

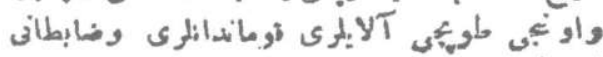

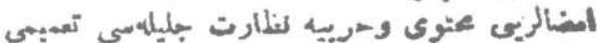

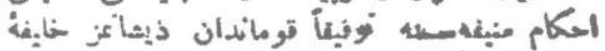

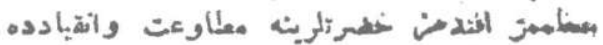

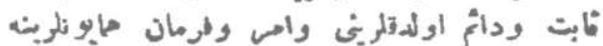

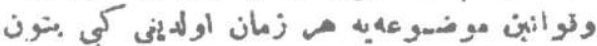

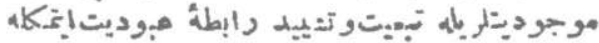

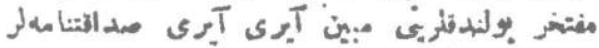

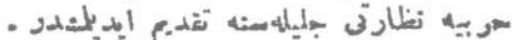
ديكر طرفدن موتعمستهكم اركاتى .رونجها آنى

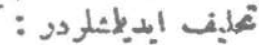

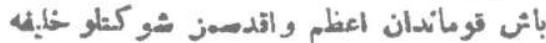

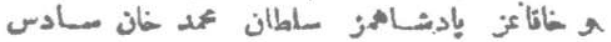

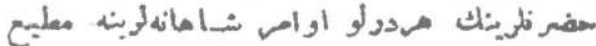

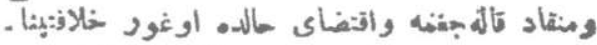

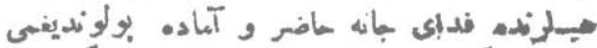

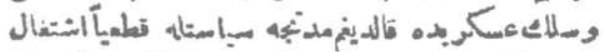

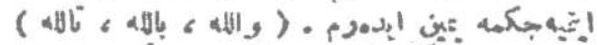

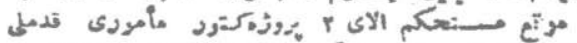

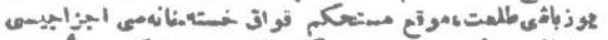

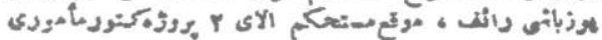

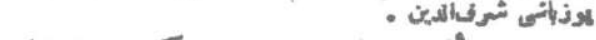

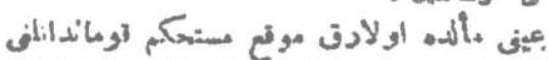

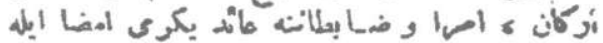

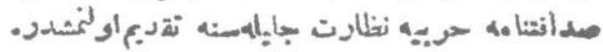

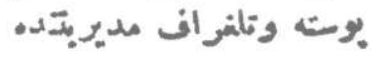

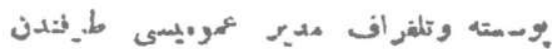

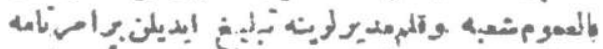

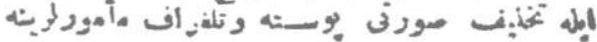

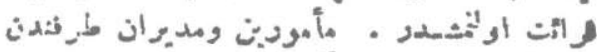

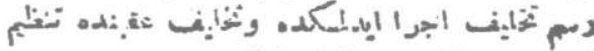

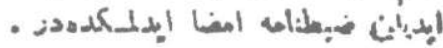

\section{Vakit, 14 Mayıs 1336/1920}

